\title{
STABILISASI VITAMIN A (RETINOL) PADA SERUM OTOLOGUS SEDIAAN SERBUK KERING MENGGUNAKAN LIOPROTEKTAN SUKROSA
}

\author{
Iman P. Maksum ${ }^{1, *}$, Lani Indrayati ${ }^{1}$, Sutarya Enus $^{2,3}$ \\ ${ }^{1}$ Departemen Kimia, Fakultas Matematika dan Ilmu Pengetahuan Alam, Univerrsitas Padjadjaran \\ ${ }^{2}$ Departemen Ilmu Kesehatan Mata Fakultas Kedokteran Universitas Padjadjaran \\ ${ }^{3}$ Pusat Mata Nasional, Rumah Sakit Mata Cicendo, Bandung \\ *Alamat Korespondensi: iman.permana@unpad.ac.id
}

\begin{abstract}
Abstrak: Peran vitamin A pada siklus penglihatan. Selain itu vitamin A punya peranan penting termasuk metoblisme, pembentukan tulang, diferensiasi epithel, embriogenesis, dan immunokompeten. Vitamin A mempromosikan diferensiasi sel konjungtiva. Pada kasus dry eye faktor epilotropik berkurang, kerusakan permukaan okuler menyebabkan kerusakan kornea dan konjungtiva yang parah. Serum otologus mengandung komponen vitamin A yang cukup banyak. Penelitian ini dilakukan stabilisasi serum otologus dengan proses liofilisasi dan menggunakan lioprotektan sukrosa dan ditentukan kadar sediaan serum serbuk kering. Tujuan penelitian ini menentukan kadar vitamin A dengan metode HPLC pada serum otologus dalam sediaan serbuk kering dengan sukrosa pada variasi suhu (suhu ruang, suhu $4{ }^{\circ} \mathrm{C}$ dan suhu $-20{ }^{\circ} \mathrm{C}$ ) serta variasi waktu penyimpanan ( 1 bulan, 3 bulan, dan 6 bulan). Hasil penelitian ini menunjukkan bahwa vitamin A (retinol) pada serum serbuk kering dengan sukrosa tidak bertahan selama waktu penyimpanan. Uji one way Anova dengan Minitab menunjukkan tidak ada perbedaan antara serum dalam bentuk natif dengan serum serbuk kering dengan sukrosa dan tanpa sukrosa pada masa simpan 0 bulan $(\mathrm{p}=0,116)$.
\end{abstract}

Kata kunci: serum otologus, dry eye, liofilisasi, retinol, HPLC

Abstract: Vitamin A has a role in the visual cycle. Other than that, vitamin A has important roles in metabolism, bone formation, epithelial differentiation, embryogenesis, and immunocompetence. Vitamin A promotes differentiation of conjunctival cells. In the case of dry eye, epilotropic factor decreases, causing severe damage to the ocular surface of the cornea and conjunctiva. Autologous serum contains abundance amount of vitamin A- components. This research was carried out by stabilization of autologous serum by lyophilization process using sucrose as lyoprotectant and vitamin A level was in the dry powder preparations. The purpose of this study was to determine the levels of vitamin A in dried autologus serum preparation using HPLC with sucrose as protectant with variation of temperature (room temperature, the temperature of $4 \circ \mathrm{C}$ and $-20{ }^{\circ} \mathrm{C}$ ) and variations in storage time (1 month, 3 months, and 6 months). Conclusions of this study was that vitamin A (retinol) at 0 months does not gave any difference in dried serum powder with or without sucrose as lyoprotectant.

Keywords: autologous serum, dry eye, lyophilized, retinol, HPLC.

\section{PENDAHULUAN}

Kasus dry eye terjadi pengurangan faktor epilotropik, kerusakan permukaan okuler menyebabkan kerusakan kornea dan konjungtiva yang parah. Vitamin A berperan penting dalam kesehatan mata, yaitu pada siklus penglihatan bentuk 11-cis- retinaldehida terikat pada rhodopsin (batang) dan iodhopsin (cone) pada residu lisin (Ball 2004). Dalam bentuk asam retinoat berperan dalam transkripsi gen mempromosikan diferensiasi sel konjungtiva (Liu et al. 2005). Serum darah manusia mengandung komponen-komponen yang sama dengan terdapat dalam air mata yaitu: EGF (epidermal growth factor), TGF- $\beta$ (transforming growth factor beta), IgA (Immunoglobin A), Vitamin A, fibronektin, dan sitokin (Quinto et al. 2008). Komponen vitamin A terdapat dalam air mata dan komposisinya lebih banyak pada serum. Vitamin A mempunyai tiga bentuk yaitu retinol, retinaldehid, dan asam retinoat. Retinol $95 \%$ terdapat dalam darah
(Catignani \& Bieri 1983). Sediaan tetes mata serum mudah rusak sehingga diperlukan penyimpanan pada suhu rendah untuk menjaga keaktifan komponen yang ada dalam serum. Masalah penyimpanan dan keeektifan dalam penggunaan serum otologus mendorong untuk membuat sediaan serum yang lebih stabil. Untuk meningkatkan stabilitas sediaan serum otologus harus disimpan pada suhu yang rendah. Penelitian ini dilakukan untuk meningkatkan stabilitas serum otologus dengan metode liofilisasi menggunakan lioprotektan sukrosa. Liofilisasi atau dikenal sebagai freeze dry merupakan suatu proses yang penting dan mapan untuk meningkatkan stabilitas jangka panjang obat-obatan yang labil, terutama dari golongan protein. Selain keuntungan dalam hal stabilitas yang lebih baik, formulasi liofilisasi juga mempermudah penanganan saat pengiriman dan penyimpanan (Tang \& Pikal 2004). Namun proses liofilisasi sendiri menghasilkan berbagai cekaman yang cenderung bisa menyebabkan destabilisasi, denaturasi, agregasi pada protein yang 
tidak terlindungi, protein yang berbeda masih bisa menolerir pada proses liofilisasi. Beberapa sakarida non-pereduksi seperti sukrosa dan trehalosa adalah stabilisator umum yang melindungi protein dari bahan kimia dan degradasi fisik dalam larutan air selama liofilisasi dan dalam proses penyimpanan berikutnya (Wang 2000). Penelitian ini menentuan kadar vitamin A pada serum otologus dalam sediaan serbuk kering dengan sukrosa dengan menggunakan metode HPLC pada pada variasi suhu (suhu ruang, suhu $4^{\circ} \mathrm{C}$ dan suhu $-20^{\circ} \mathrm{C}$ ) serta variasi waktu penyimpanan (1 bulan, 3 bulan dan 6 bulan).

\section{BAHAN DAN METODE}

Penelitian ini merupakan studi komparatif dan uji non klinis. Analisis dengan menggunakan metode HPLC ( High Performance Liquid Chromatograpy).

\section{Bahan}

Serum dari tiga donor sukarelawan, sukrosa, natrium klorida fisiologis, metanol, etanol, heksana, dietil eter, akuabides, retinol standar (Retinol lot BCBL 139V synthetic, $\geq 95 \%$ HPLC crystalline Sigma Aldrich).

\section{Alat}

Tabung appendorf 1,5 mL, pipetman, tip, freeze dryer (Christ Alpha 1-2 LD plus, vaccum pump R2 2.5 S/N 3418360), HPLC (Waters 299 photodiode array detector, Waters 1525 binary HPLC pump, column C-18).

\section{Preparasi Serum}

Sejumlah $100 \mathrm{~mL}$ darah diambil dan didiamkan selama 2 jam agar membeku, setelah membeku darah disentrifugasi dengan kecepatan $5000 \mathrm{~g}$ selama 10 menit. Setelah serum terbentuk di tampung dalam tabung. Serum yang diperoleh dilarutkan dengan $\mathrm{NaCl}$ fisiologis dengan konsentrasi akhir $20 \%$ (v/v) dengan penambahan lioprotektan sukrosa $(60 \mathrm{mM})$. Larutan kemudian dikeringkan dengan metode beku kering (freeze dry). Kemudian disimpan pada suhu ruang, suhu $4^{\circ} \mathrm{C}$ dan suhu $-20^{\circ} \mathrm{C}$. Periode waktu 1 bulan, 3 bulan dan 6 bulan dilakukan analisis vitamin A dengan metode HPLC.

\section{Persiapan Sampel Retinol}

Serum diambil sebanyak $100 \mu \mathrm{L}$ ditambahkan $100 \mu \mathrm{L}$ heksana kemudian dilakukan sentrifugasi 800 $g$ selama 5 menit dan ambil supernatan. Kemudian supernatan dievaporasi pada water bath dengan suhu $60^{\circ} \mathrm{C}$. Setelah itu ambil residu dan ditambahkan 25 $\mu \mathrm{L}$ dietil eter dan $75 \mu \mathrm{L}$ metanol. Sampel retinol siap diinjeksikan ke dalam injektor, set detektor pada panjang gelombang $280 \mathrm{~nm}$, dan flow rate 1 $\mathrm{ml} /$ menit. Fasa mobil HPLC menggunakan metanol $950 \mathrm{~mL}$ dicampur dengan $50 \mathrm{~mL}$ air (metanol: air = 95:5, v/v), sebelum digunakan sebagai eluen maka disonifikasi terlebih dahulu. Fasa diam menggunakan kolom C-18. Retinol standar (Retinol lot BCBL 139V synthetic, $\geq 95 \%$ HPLC crystalline Sigma Aldrich) dilarutkan dengan etanol, waktu retensi retinol standar berada pada posisi 4,5 menit. Sebanyak 20 $\mu \mathrm{L}$ sampel retinol diinjeksikan ke dalam kolom dan retinol berada dalam retensi waktu 4,5 menit sesuai dengan retinol standar yang berada di posisi tersebut.

\section{Interpretasi Data Hasil Kromatogram}

Analisis data menggunakan one-way ANOVA deangan software MINITAB 15.

\section{HASIL DAN PEMBAHASAN}

Darah yang diambil dari responden sebanyak 100 $\mathrm{mL}$, sampel darah dari tiap responden disentrifugasi dengan kecepatan $5000 \mathrm{~g}$ selama 10 menit dan didapatkan serum sebanyak $20 \mathrm{~mL}$ serum dengan penambahan natrium klorida fisiologis $(0,9-1 \%)$. Setelah itu dilakukan analisis awal dan penambahan sukrosa $60 \mathrm{mM}$ pada sampel serum. Kemudian sampel serum diliofilisasi dengan freeze dryer.

Tabel 1. Hasil perolehan serum dari darah donor

\begin{tabular}{ccc}
\hline Donor & $\begin{array}{c}\text { Volume } \\
\text { darah }(\mathrm{mL})\end{array}$ & $\begin{array}{c}\text { Volume serum } \\
\text { yang diambil } \\
(\mathrm{mL})\end{array}$ \\
\hline 1 & 100 & 20 \\
2 & 100 & 20 \\
3 & 80 & 20 \\
\hline
\end{tabular}

Dari hasil analisis kadar retinol dengan metode HPLC didapatkan kadar vitamin A sebesar 38,71 ppm. Serum setelah liofilisasi dengan liprotektan sukrosa pada pengukuran 0 bulan diperoleh kadar vitamin A 3,31 ppm dan tanpa sukrosa 11,44 ppm.

Kandungan retinol pada serum (natif) menurun kadarnya setelah menjadi bentuk serbuk kering (dengan sukrosa) ataupun serbuk kering (tanpa sukrosa) seperti ditunjukkan pada Tabel 2. Walaupun terjadi penurunan kadar retinol dalam serum otologus serbuk kering menggunakan lioprotektan sukrosa masa simpan 0 bulan dengan natif namun secara statitik tidak terjadi perbedaan kadar retinol antara serum serbuk kering dengan sukrosa dan natif nilai $p=0,116$. Kadar retinol natif menunjukan konsentrasi yang tinggi pada serum segar yang belum mendapat perlakuan liofilisasi dan lioprotektan sukrosa terlihat puncak yang tinggi pada retensi waktu 4,5 menit (Gambar 1). Pada analisis serum serbuk kering masa simpan 1 bulan berikutnya hasil kromatogram menunjukkan puncak yang sangat kecil sekali pada retensi waktu 4.5 menit sehingga perhitungan kadar 
Tabel 2. Rerata kadar vitamin A (retinol) natif dan serum serbuk kering masa simpan 0 bulan.

\begin{tabular}{lccc}
\hline \multicolumn{1}{c}{ Sampel } & $\begin{array}{c}\text { Rerata kadar retinol } \\
(\mathrm{ppm})\end{array}$ & $\begin{array}{c}\text { Simpangan } \\
\text { baku }\end{array}$ & $\mathrm{P}$ \\
\hline Natif & 38,71 & 5,91 & \\
Serum serbuk kering dengan sukrosa & 3,31 & 0,26 & 0,116 \\
Serum serbuk kering tanpa sukrosa & 11,44 & 2,03 & \\
\hline
\end{tabular}

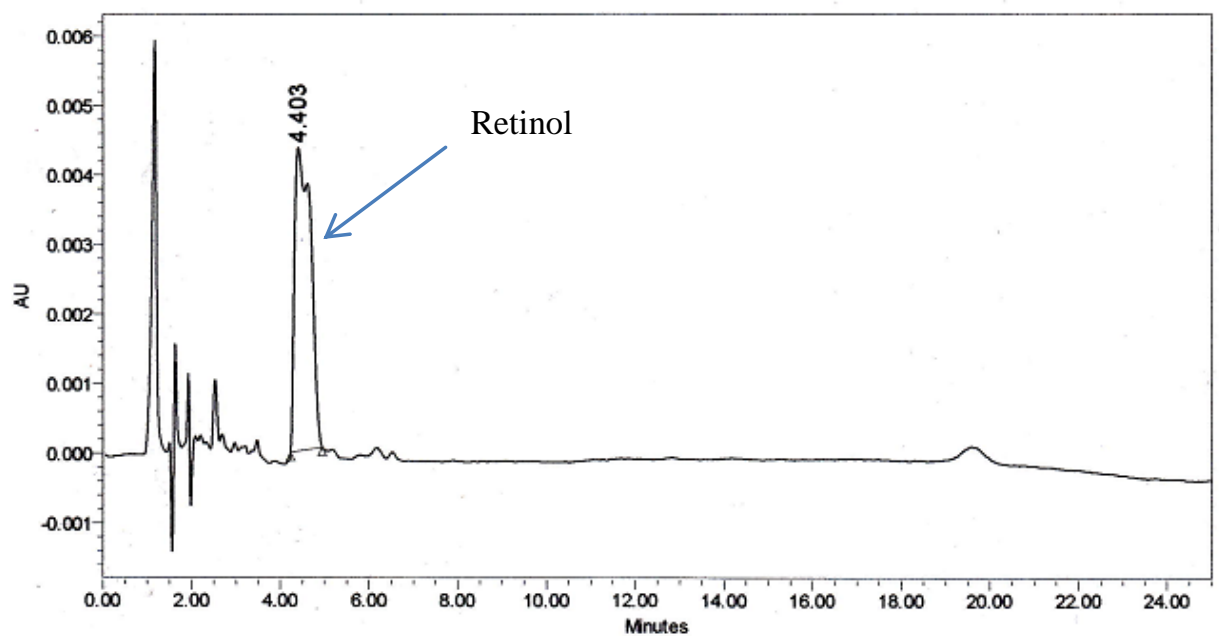

Gambar 1. Hasil kromatogram HPLC serum natif. Retinol terdeteksi pada waktu retensi 4,403 menit. Set detektor pada panjang gelombang $280 \mathrm{~nm}$, dan flow rate $1 \mathrm{~mL} /$ menit. Fasa mobil HPLC menggunakan metanol $950 \mathrm{~mL}$ dicampur dengan $50 \mathrm{~mL}$ air (metanol: air=95:5, v/v), Fasa diam menggunakan kolom C-18. Retinol standar (Retinol lot BCBL 139V synthetic, $\geq 95 \%$ HPLC crystalline Sigma Aldrich) dilarutkan dengan etanol, waktu retensi retinol standar berada pada posisi 4,5 menit.

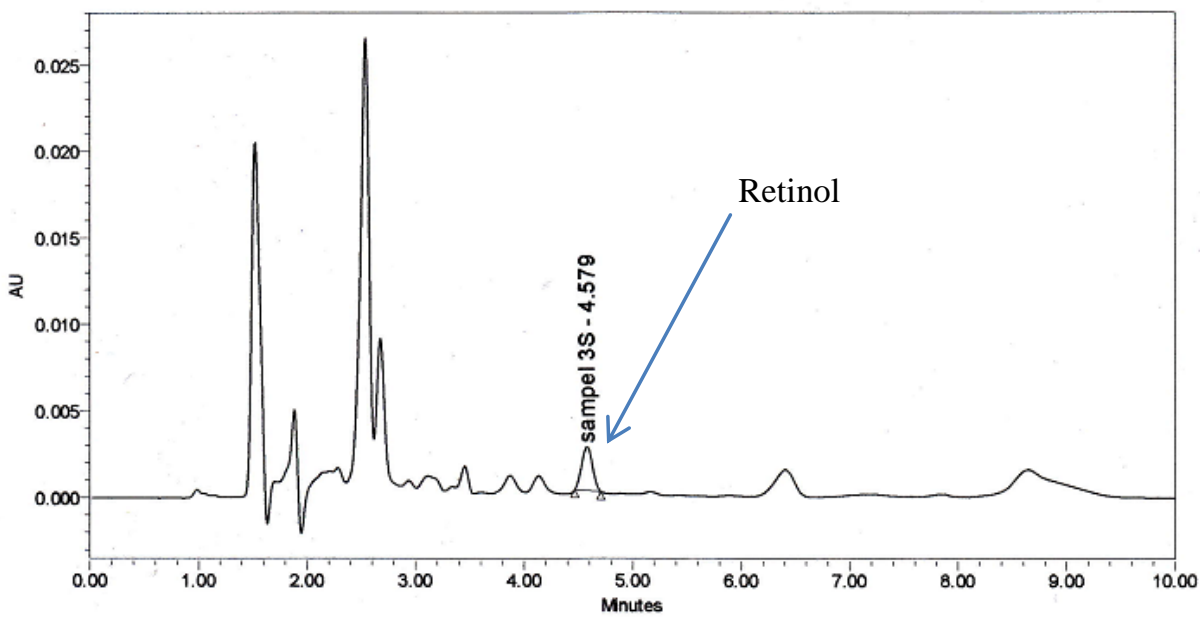

Gambar 2. Hasil Kromatogram HPLC Serum Serbuk Kering dengan Lioprotektan Sukrosa Pada Masa Simpan 0 Bulan. Retinol terdeteksi pada Waktu Retensi 4,579 menit. Set detektor pada panjang gelombang $280 \mathrm{~nm}$, dan flow rate $1 \mathrm{~mL} /$ menit. Fasa mobil HPLC menggunakan metanol $950 \mathrm{~mL}$ dicampur dengan $50 \mathrm{~mL}$ air (metanol: air=95:5, v/v), Fasa diam menggunakan kolom C-18. Retinol standar (Retinol lot BCBL 139V synthetic, $\geq 95 \%$ HPLC crystalline Sigma Aldrich ) dilarutkan dengan etanol, waktu retensi retinol standar berada pada posisi 4,5 menit. 


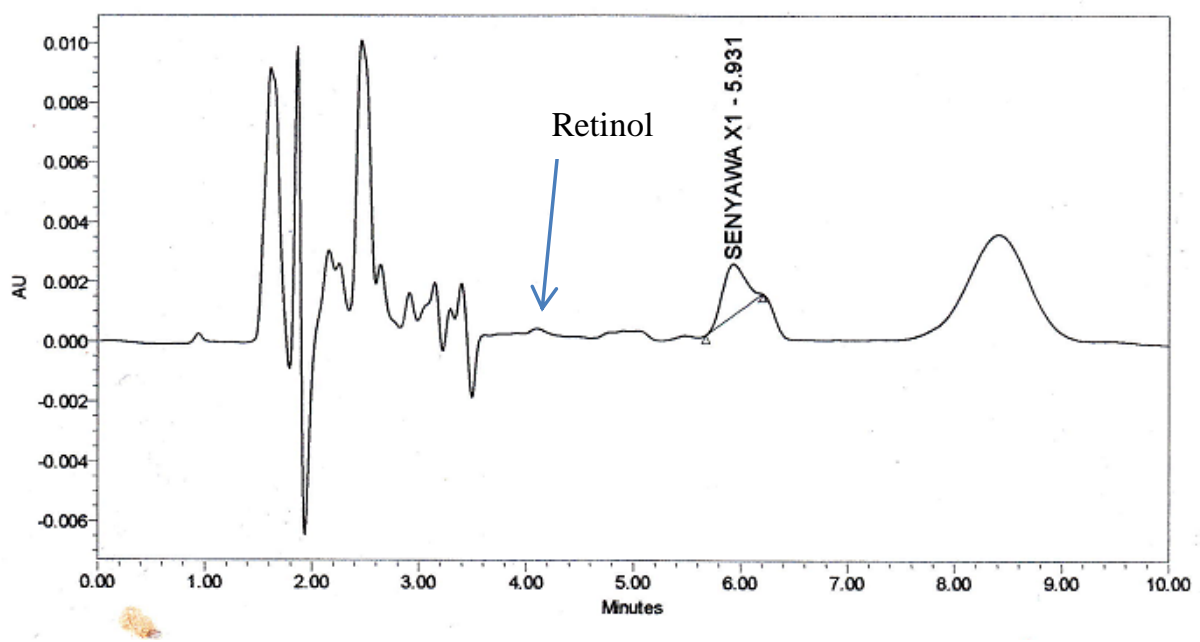

Gambar 3. Hasil Kromatogram HPLC Serum Serbuk Kering Dengan Lioprotektan Sukrosa Pada Masa Simpan 30 hari. Puncak retinol sangat kecil terdeteksi pada retensi waktu 4,5 menit. Set detektor pada panjang gelombang $280 \mathrm{~nm}$, dan flow rate $1 \mathrm{~mL} /$ menit. Fasa mobil HPLC menggunakan metanol $950 \mathrm{~mL}$ dicampur dengan $50 \mathrm{~mL}$ air (metanol: air=95:5, v/v), Fasa diam menggunakan kolom C-18. Retinol standar (Retinol lot BCBL 139V synthetic, $\geq 95 \%$ HPLC crystalline Sigma Aldrich ) dilarutkan dengan etanol, waktu retensi retinol standar berada pada posisi 4,5 menit.

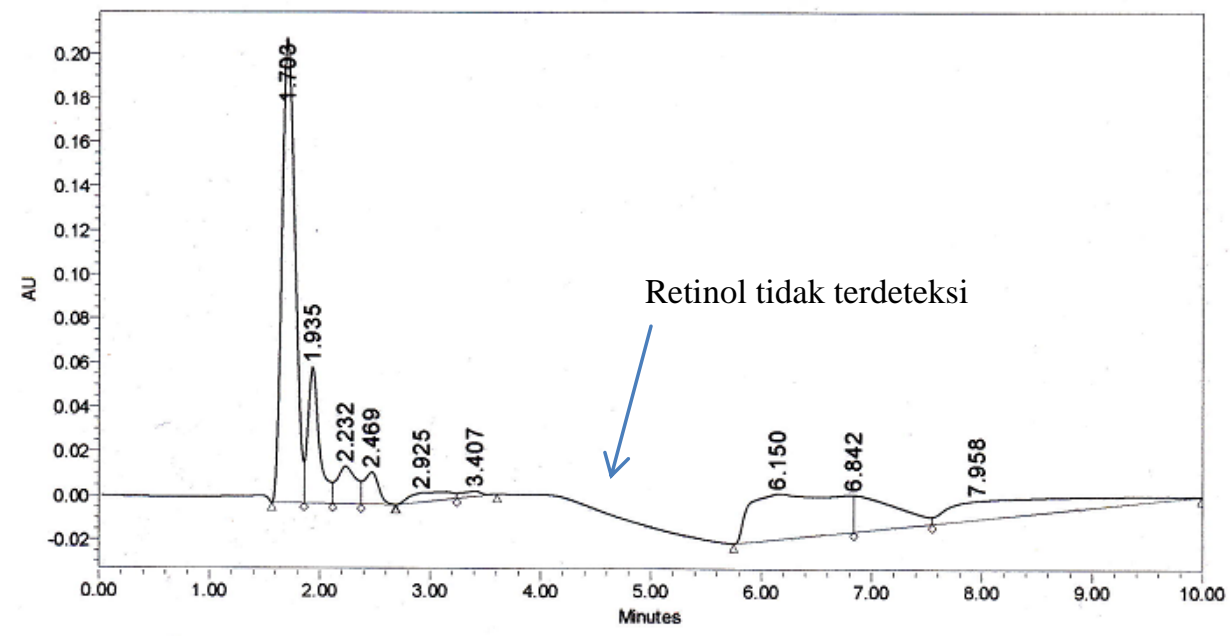

Gambar 4. Hasil Kromatogram HPLC Serum Serbuk Kering Dengan Lioprotektan Sukrosa Pada Masa Simpan 3 bulan. Puncak retinol tidak terdeteksi pada retensi waktu 4,5 menit. Set detektor pada panjang gelombang 280 $\mathrm{nm}$, dan flow rate $1 \mathrm{~mL} /$ menit. Fasa mobil HPLC menggunakan metanol $950 \mathrm{~mL}$ dicampur dengan $50 \mathrm{~mL}$ air (metanol: air=95:5, v/v), Fasa diam menggunakan kolom C-18. Retinol standar (Retinol lot BCBL 139V synthetic, $\geq 95 \%$ HPLC crystalline Sigma Aldrich) dilarutkan dengan etanol, waktu retensi retinol standar berada pada posisi 4,5 menit.

retinol sulit ditentukan (Gambar 2). Pada masa simpan 3 bulan pada suhu ruang, $4^{\circ} \mathrm{C}$, dan suhu $20^{\circ} \mathrm{C}$ retinol tidak terdeteksi pada retensi waktu 4,5 menit HPLC (Gambar 3). Menunjukan semakin berkurangnya kadar vitamin A selama masa penyimpanan dan suhu penyimpanan. Perhitungan kadar dilakukan sampai dengan masa simpan 0 bulan saja.

Serum terdapat berbagai komponen yang mirip dengan air mata, di antaranya komponen vitamin A.
Sebelum proses kering beku dilakukan analisis kadar vitamin A terhadap serum natif. Kadar vitamin A serum natif diperoleh 38 ppm mendekati nilai kadar serum yang dikemukan Geerling et al. (2004) yaitu 48 ppm. Selama pengeringan serum otologus menggunakan freeze dryer total sekitar 24 jam. Setelah menjadi serbuk kering dilakukan analisis kadar vitamin A dan penyimpanan serum pada suhu berbeda. Analisis pada serbuk kering dilarutkan kembali dengan air destilasi bertingkat sampai pada 
volume yang sama seperti semula yaitu $1 \mathrm{~mL}$. Stabilitas serum otologus dalam sediaan serbuk kering dengan lioprotektan sukrosa tidak dapat mempertahankan kadar vitamin A. Terjadi penurunan kadar vitamin A (retinol) dari natif menjadi serum serbuk kering lioprotektan sukrosa (Tabel 2) dan pada masa simpan analisis berikutnya tidak bisa ditentukan perhitungan kadar karena pada masa simpan 1 bulan puncak kromatograf sangat kecil. Hal ini karena selama proses penghilangan molekul air dengan proses liofilisasi mengurangi degradasi protein baik secara kimiawi maupun fisika namun proses dehidrasi juga sering merusak struktur yang pada akhirnya menyebabkan kesalahan pelipatan dan agregasi protein ketika dilarutkan kembali dalam air (Arakawa et al. 2001). Proses liofilisasi mengakibatkan agregasi kimia seperti oksidasi (Wang et al. 2000). Oksidasi ini salah satu penyebab menurunnya kadar vitamin A. Sifat vitamin A yang mudah teroksidasi baik oleh oksigen dari udara dan pengaruh cahaya. Selama penyimpanan instabilitas dapat terjadi seperti agregasi, degradasi kimia seperti deamidasi, reaksi pencoklatan, oksidasi, hidrolisis, dan perubahan formasi ikatan disulfida. Agregasi protein fisik dan kimia dapat terjadi selama penyimpanan. Agregasi fisik terjadi interaksi non kovalen. Agregasi kimia terjadi interaksi kovalen yaitu perubahan atau formasi ikatan disulfida (Wang et al. 2000). Liofilisasi serum otologus dengan lioprotektan menurunkan kadar vitamin A. Penelitian sebelumnya (Enus dkk. 2011) mampu mempertahankan kadar protein EGF (epiderrmal growth factor) selama masa simpan 2 bulan. Ini menunjukkan bahwa liofilisasi mampu mempertahankan protein sedang untuk mempertahankan vitamin kurang efektif. Jadi untuk serum otologus serbuk kering dengan sukrosa sebagai tetes mata perlu tambahan vitamin A dari luar. Untuk melindungi vitamin A dari kerusakan perlu perlakuan khusus dalam penyimpanan seperti udara dalam keadaan inert, terhindar cahaya, terhindar logam dan lingkungan asam yang kuat, penambahan anti oksidan dan dilapisi dengan matriks seperti gelatin dan komplek kimia dengan senyawa lain (Baurnfeind \& Klaui 1981). Kadar vitamin A dalam air mata normal 0,02 mg/L (Geerling et al. 2004).

\section{KESIMPULAN}

Vitamin A (retinol) pada serum serbuk kering dengan sukrosa tidak bertahan selama proses liofilisasi dan waktu penyimpanan, hal ini menunjukkan bahwa proses liofilisasi dengan penambahan sukrosa hanya efektif untuk mempertahankan kadar protein, tidak untuk stabilisasi vitamin A.

\section{Ucapan Terima Kasih}

Kami mengucapkan terima kasih kepada RS. Hasan Sadikin Bandung unit patologi atas pengumpulan darah donor.

\section{DAFTAR PUSTAKA}

Arakawa, T., Prestelki, S.J., Kenney, W.C. \& Carpenter, J.F. (2001). Factors affecting shortterm and long term stabilities of protein. Advanced Drug Delivery Review. 46 (1-3): 307326.

Ball, G.F.M, (2004). Vitamins and Their Role in The Human Body. New York: Blackwell Publishing.

Bauernfeind, J.C. (1981). Carotenoids as colorants and vitamin A precursors. Technological and nutritional applications. New York: Academic Press, Inc.

Catignani, G.L. \& Bieri, J.G. (1983). Simultaneous determination of retinol and $\alpha$-tocopherol in serum or plasma by liquid chromatography. Clinical Chemistry. 29(4): 708-712.

Enus, S., Maksum, I.P., Ishmayana, S., Subroto, T. \& Soemitro, S. (2011). Stabilisasi Tetes Mata Serum Otologus Dalam Sediaan Serbuk Dengan Metode Freeze Drying Menggunakan Lioprotektan. Laporan Penelitian. Pusat Mata Nasional Rumah Sakit Cicendo.

Geerling, G., Maclennan, S. \& Hartwig, D. (2004), Autologous serum eye drops for ocular surface disorders. British Journal of Ophthalmology. 88: 1467-1474.

Liu, L., Hartwig, D., Harloff, S., Herminghaus, P., Wedel, T. \& Geerling, G. (2005). An optimised protocol for the production of autologous serum eyedrops. Graefe's Archive for Clinical and Experimental Ophthalmology. 243: 706-714.

Quinto, G.G., Campos, M. \& Behrens, A. (2008), Autologous serum for ocular surface diseases. Arquivos Brasileiros de Oftalmologia. 71: 4754.

Tang, X. \& Pikal, M. (2004). Design of freeze-drying processes for pharmaceuticals: Practical advice. Pharmaceutical Research. 21: 191-200.

Wang, W. (2000). Lyophilization and development of solid protein pharmaceuticals. International Journal of Pharmaceutics. 203(1): 1-60. 